\title{
A ESCOLA CATÓLICA, UMA HISTÓRIA \\ DE SERVIÇO AO POVO E À NAÇÃO BRASILEIRA
}

\author{
Manoel Alves, FMS
}

\begin{abstract}
"Um trabalho sobre a história da Escola Católica não pode ser desligado da história da Igreja Católica, instituição que a gera, dando forma, ideologia e financiando suas atividades." (HADDAD, 1981)
\end{abstract}

\section{Resumo}

A presença da Igreja no campo da Educação tomou os contomos que os distintos momentos conjunturais de nossa histónia lhe imprimiram. Os momentos de dificuldades superados, os modelos de seu perfil juńdico adaptados às transformações de regime, das formas de govemo e das constituições, e as crises internas alavancando novo ardor apostólico, vinham apenas confirmar a certeza de que, na sua Missão, Evangelização e Educação são indissociáveis.

Diante das evidências dessa história, feita de entranhado serviço à juventude brasileira na constituição social, cultural e religiosa de nosso povo, fica fácil atestar a relevância da ação da Escola Católica ontem e hoje. A trajetória da Igreja no campo da educação no Brasil não foi sempre isenta de tensões e conflitos sociais. Sua opção também se viu eivada de contradições, sobretudo quando pendeu particularmente a favor da educação das elites.

Enormes são para o Brasil os benefícios em poder continuar contando com a participação desta instituição, a Escola Católica, no seu desenvolvimento social e econômico, na formação das novas gerações às dimensões ética e de cidadania, e na consolidação de uma real democracia.

A sua tradição sem igual, a seriedade de seus princípios e a qualidade de seus serviços educacionais habilitam-na sobejamente a estar presente, hoje e amanhã, no Sistema Nacional de Educação de nossa Pátria, certa de poder continuar a oferecer a sua decisiva parcela de contribuição na construção da Nação.

* Professor de Sociologia da Educação no Curso de Pedagogia e Letras

Professor do Programa de Mestrado em Educação na Universidade Católica de Brasília

Integrante do Grupo de Pesquisa em Gestão e Políticas Educacionais da mesma Universidade

Presidente do Conselho Curador da Fundação Universa - FUNIVERSA - DF

Assessor da UBEC - Mantenedora da Universidade Católica de Brasília

Consultor na Área de Gestão Educacional de diversas Instituições de Educação Privada 
O tema do conflito na Igreja se origina freqüentemente na tensão entre suas opções fundamentais e os limites e imperativos das diversas conjunturas sociais e políticas em que se encontra. Este conflito se manifestará nos distintos períodos da presença da Igreja no campo educativo, especialmente quando sua presença educativa privilegia as elites e seu discurso pastoral aponta para as camadas populares.

Palavras-chave: Educação Católica, Educação Confessional, Elites, Educação Privada, Tensões Sociais.

\section{Summary}

The Church presence in the al field was marked by the imprint of the different historical moments in our history.

With the difficult moments already overcome, with the models of its juridical profile already adpated to the transformations of the political regime and ists forms of government and political constitutions, with the internal crises raising a new apostolic zeal, it became clear that evangelization and education are inseprable in their aims.

In front of the evidence of that reality, made up of a wholehearted devotion to the Brasilian youth in the social, cultural and religious spheres of society, it is easy to witness to the relevance of the catholic school influence yesterday and today.

The history of the church in the educational field in Brazil was not always immune to tensions and social conflit. Its options were also tainted with contradictions, above al when it took sides with the education of the privileged groups.

The benefits derived by Brazil from the ongoing role played by the catholic school in the social and economic development, in bringing up the new generations to ethical and civic values, in the consolidation of a real democracy... are enormous.

Its unequalled tradition, the seriousness of its principles and the quality of its educational services qualify the church by and large to be present, today and tomorrow, in the education national system of our country, certain to carry on offering its decisive contribution to the build-up of the nation.

A conflicting situation in the church often arises from the tension between its fundamental options and the limits and demands of the different social andpolitical junctures of the moment.

This conflict manifestes itself time and again within the realm of the church presence in the educational field, especially when its educational work favours the privileged groups and its pastoral speech leans towards the popular classes of society.

Keywords: catholic education - confessional education - privileged groups - private education - social tensions. 


\section{A Igreja Ca tólica no Brasil Colônia}

O modelo da Igreja no Brasil, e mais amplamente na América LusoEspanhola, implantado no momento da Descoberta, reproduzia o existente nos países colonizadores, a saber, aquele da Cristandade. ${ }^{1}$ Assim, a Evangelização como presença e ação da Igreja foi componente inerente ao processo da descoberta e da colonização do Novo Mundo.

A ação da Igreja, no Brasil, desde o começo de sua aventura evangelizadora, ainda que de acordo com o Estado, era, no entanto, submissa a um absoluto poder e controle temporal que só este detinha. A Igreja tinha, pois, necessidade da ajuda da Coroa Portuguesa para financiar sua ação. Por outro lado, ela subordinava sua "Missão Espiritual Evangelizadora" aos interesses de outra ordem, os do Estado.

Mais precisamente, pelo sistema do "Padroado", ${ }^{2}$ certas funções "eclesiais" eram atribuídas aos govemos da Colônia que exerciam assim um tríplice controle:

1. Controle Patrimonial - construção dos edifícios de culto, residências e conventos (isto compreendia a propriedade do temeno e as obras de construção), administração do dízimo etc.

Controle Político - a escolha, nomeação e pagamento do clero e do episcopado.

2. Controle Ideológico e Cultural - censura e autorização para as publicações e impressos distribuídos, a aprovação de documentos, controle do sistema de ensino.

A perda progressiva da autoridade papal sobre a Igreja no Brasil favoreceu desvios institucionais os mais variados: impedimento de sua expansão organizacional; raras criações de paróquias e dioceses; ${ }^{3}$ ausência de seminários até 1739; falta de padres etc. Uma presença fortemente sentida na definição do perfil do catolicismo no Brasil, pelo viés das Confrarias Religiosas, ${ }^{4}$ foi a dos leigos.

Durante a maior parte do peníodo colonial (1500-1759), em razão de um clero secular reduzido, as tarefas da catequese e a do ensino no Brasil ficariam ao encargo de Ordens Religiosas, sobretudo dos Franciscanos e dos Jesuítas, mas também dos Oratorianos, dos Dominicanos, dos Beneditinos, dos Carmelitas e dos Capuchinhos. Como religiosos, eles tinham suas estruturas próprias, muito mais desenvolvidas, eficazes e autônomas que a do clero secular, ${ }^{5}$ constituindo-se em regime de caráter privado, mas que contava com o apoio financeiro do Estado.

\section{A Educação Ca tólica no Brasil Colônia}

A ação da Igreja foi muito fraca durante os primeiros decênios que

Revista Diálogo Educacional, Curitiba, v. 3, n.7, p. 37-62, set./dez. 2002. 
sucederam a descoberta do Brasil. No que concerne à ação educacional, nenhuma atividade foi exercida pela Igreja, neste peńodo.

Depois de ter criado, em 1532, as Capitanias Hereditárias, com a intenção de ocupar, defender e povoar as terras descobertas pouco antes, a Coroa Portuguesa instalou um Governo Geral da Colônia, a fim de remediar as dificuldades deste primeiro sistema. ${ }^{6}$

Entre as preocupações do Rei de Portugal, no momento de criar o Governo Geral, havia aquela de promover a conversão dos indígenas ao Catolicismo (e sua docilidade à exploração do trabalho) pela ação dos missionánios e de garantir a todos os habitantes das novas terras a catequese e a instrução, confiando esta tarefa à Igreja

Com o Governador Geral Tomé de Souza, chegam ao Brasil seis Jesuítas $^{7}$ (4 Padres e 2 Irmãos), cujo superior era o Padre Manoel da Nóbrega. Eles tinham a missão de ensinar a língua portuguesa, a doutrina cristã, a leitura e a escrita. Assim, nos internatos dos jesuítas nasciam as obras educacionais mais importantes dos três primeiros séculos da Histónia Brasileira.

Havia, pois, no começo, uma grande preocupação da Coroa com aculturação e a evangelização dos indígenas. A educação dos jesuítas introduziu no Brasil um prolongamento da política de colonização portuguesa. Disso resultou para a Igreja uma espécie de servidão ao poder que a obrigou a reproduzir na sua ação educativa os princípios sociais estabelecidos pela Metrópole.

Evidentemente, as iniciativas colonizadoras de Portugal, não somente no Brasil, mas também na costa ocidental da África e da Ásia, eram sobretudo motivadas pelos interesses econômicos. Esta ação foi sempre animada pela burguesia mercantil de Lisboa.

Pode-se constatar que (...) o objetivo dos colonizadores era o lucro, e a função da população colonial era propiciar tais lucros às camadas dominantes metropolitanas. No entanto, para que a empresa funcionasse, estes lucros não poderiam se concentrar exclusivamente nos grupos extemos citados (as camadas dominantes metropolitanas). Uma parte, pequena é certo, deveria permanecer na Colônia com a camada que dirigia intemamente a atividade produtiva. (RIBEIRO, 1989)

Pouco a pouco, constituiu-se no Brasil Colônia uma pequena burguesia local, dominante, mas minoritária em relação ao conjunto da população que a habitava. As demandas desta camada social levaram a uma alteração do projeto inicial dos jesuítas quando foram enviados a estas terras, iniciando-se um projeto de Educação para as Elites no Brasil. 


\section{Um conflito de opções}

O tema do conflito na Igreja se origina freqüentemente na tensão entre suas opções fundamentais e os limites e imperativos das diversas conjunturas sociais e políticas em que se encontra. Este conflito se manifestará nos distintos períodos da presença da Igreja no campo educativo.

Olhando a Sociedade Brasileira no século XVI, vêem-se dois grandes blocos distintos: de um lado a pequena burguesia (sistema patriarcal da camada dirigente), de outro os indígenas e os negros (escravidão). O modelo econômico era o sistema agrário, de base escravagista. A exploração vegetal e a produção do açúcar foram a base da economia colonial até a metade do século XVII.

Se, em princípio, os jesuítas vieram ao Brasil para responderem ao pedido do Governo Geral, para a catequese e a instrução dos indígenas o processo de nascimento de um grupo dominante os levou a mudar a opção inicial. O que significou abandonar, em boa parte, o trabalho junto aos indígenas.

Com efeito, os planos elaborados pelo Padre Manoel da Nóbrega, Supenior do grupo de jesuítas, revela um desejo de fidelidade à Missão que lhes foi atribuída, a de catequizar e de instruir os indígenas. No entanto, ele perceberá que, sendo os únicos mestres da educação na Colônia, seria importante educar também os filhos dos colonos, a partir de uma base comum.

O plano dos estudos propriamente dito foi elaborado de forma diversificada, com o objetivo de atender à diversidade de interesses e das capacidades. Começando pelo aprendizado do português, incluía o ensino da doutrina cristã, a escola de ler e escrever. Daí em diante, continua, em caráter opcional, o ensino de canto orfeônico e de música instrumental, e uma bifurcação tendo em um dos lados o aprendizado profissional e agrícola e, de outro, aula de gramática e viagem de estudos à Europa. (RIBEIRO, 1989)

O cuidado com a aprendizagem profissional e agnícola revela, nestes princípios da colonização, a preocupação de dar uma educação adaptada ao contexto local e às necessidades da Colônia. O plano foi seguido, e os jesuítas se puseram a serviço de uma educação para todos.

Entretanto, esta primeira orientação na ação dos jesuítas só começa a evoluir a partir de 1556, no momento da publicação das Constituições da Companhia de Jesus.

“ (...) é verdade que em princípio, a organização dos jesuítas se fez nos moldes de uma escola visando uma certa reciprocidade de cultura e aproximação entre os grupos, iniciando-se pela escola de ler e escrever como foram as escolas de São Salvador e de São Vicente, em 1552, gradativamente esta linha estabelecida por Nóbrega vai sendo deixada de lado". (HADDAD, 1981)

A fidelidade ao plano de ação original exigirá muito empenho de um grupo de jesuítas e do Padre Manoel da Nóbrega (até o fim de sua vida em 1570). Esta fidelidade provocou conflitos com seus confrades e com seus Superiores. 
Vejamos o que disse G. Beaulie a este respeito: Já em 1559, com a posse do padre jesuíta Luiz da Grã, no provincialato do Brasil, a obra de Manoel da Nóbrega seria condenada. Era o novo caminho que procurou uma maior solidez na ação e estabilidade no apostolado através da educação das elites sociais. Em 1586, a Sociedade de Jesus estabeleceu as suas diretrizes educacionais, optando pelo ensino secundário, o Superior, (sic) como meio de formar líderes leigos. Em 1599, aprovou a "Ratio Studiorum", a ser seguida no mundo inteiro e em função da qual reestruturou as suas instituições no Brasil, transformando-as em colégios para o ensino das letras e artes liberais. Esta orientação encaminhou-a naturalmente para educar, de preferência, os membros das famílias mais importantes e para ministrar-lhes um ensino do tipo clássico, humanístico, literário, acadêmico e abstrato, que era o ideal da época. (BEAULIEU, 1996)

Fica, pois, evidenciado que o plano inicial é cada vez mais abandonado. Por outra, o plano que tende a ser adotado assume um perfil que leva a uma distância crescente da instrução dos indígenas, dos mamelucos e outros, até dela privá-los totalmente daí por diante. Os índios serão apenas catequizados, e a instrução propriamente dita será reservada aos brancos descendentes dos colonizadores.

O projeto corporativista da Igreja, visanda: aumentar sempre o número de seus fiéis, conforme as diretivas do Concílio de Trento, no contexto da Contra-Reforma e do projeto do Estado, e inculcar em todos os princípios da docilidade no momento em que cresce a hegemonia da burguesia mercantil que explorava a Colônia; levou-a a manter a catequese para os outros (os não brancos, evidentemente). Como podemos observar logo a seguir no texto original de Zind apud Avanzini et al. extraído do Siècle à nos jours.

Le Concile de Trente se contenta donc de rappeler les anciennes tradition éducatives et de reaffirmer les droits et les devoirs des évêques et des prêtres. C'est ainsi que le 17 juin 1546, la cinquième session demandait aux prêtres d'assurer le catéchisme domincal en pourvoyant " par eux-mêmes ou par d'autres personnes capables, au moins les dimaches et jours fériés, à la nourriture des populations dont ils avaient la charge, en leur enseignant les vérités nécessaires au Salut" (Acta Concilium Tridentinum) (...) Dès le 6 décembre 1563, les décrets tridentins étaient ratifiés (...) par les rois de Pologne et du Portugal, (...).

\section{A educação das elites no Brasil colonial}

A organização da Educação das Elites no Brasil-Colônia começou sob a égide dos jesuítas, que se dedicaram quase exclusivamente a este propósito. A hegemonia política de uma minoria de funcionários públicos, de proprietários de terras e de donos de engenhos de cana sobre a maioria 
de colonos brancos, nativos, mestiços e escravos negros, definiu a direção da educação.

Fica estabelecido que só os do primeiro grupo teriam acesso à educação, e ainda somente um grupo muito seleto entre esses. Pois os mais velhos deviam se ocupar somente da administração dos negócios familiares, sendo as mulheres preparadas para os afazeres domésticos. Em seguida, entendia-se que o segundo filho seria o homem letrado, o representante político dos interesses da família e da Colônia junto aos poderes públicos locais e metropolitanos. Se houvesse um terceiro filho, este seria enviado ao seminário para ser padre, garantindo, assim, o acesso à Igreja e a tudo que daí decorria.

Os colégios, mantidos no começo pela Corte, recebem, daí por diante, subsídios provenientes dos impostos da Colônia, que apenas começara a se desenvolver ao final do século XVI. ${ }^{8}$ Educação de acesso restrito ou privado às expensas do erário público.

Esta minoria que teve acesso à educação, e dispunha de recursos financeiros próprios, decidia, também, sobre a organização e a orientação do sistema de ensino. Isso era prerrogativa da elite de então. Portanto, as escolas e as missões para os indígenas, que admitiam, eventualmente, os filhos dos colonos, começaram a desaparecer, e "(...) a Igreja Católica, com suas mãos atadas dentro do regime do Padroado, que lhe propiciou um baixo nível de organização e de unidade ideológica, acabou por fazer de sua obra missionária e educacional a base da formação das elites coloniais." (HADDAD, 1981)

Neste mesmo contexto, a Campanhia de Jesus que tinha como primeiro objetivo o encargo de evangelizar e de catequizar toda a população da Colônia, especialmente os índios, modificou sua política, de acordo com as diretrizes e interesses da Ordem e a conjuntura sociopolítica, ocupando-se quase exclusivamente da educação das elites. Poder-se-ia, assim sendo, concordar com Fernando Azevedo, quando diz que "a vocação dos Jesuítas não era, certamente, a de se ocupar da educação primária ou profissional, mas da educação das classes dirigentes, aristocráticas, baseada no ensino das humanidades clássicas". (AZEVEDO, 1958)

Esta exclusividade de acesso à escola permitiu à elite colonial, já detentora do poder político e dos bens econômicos, tornar-se proprietária dos bens culturais. Todos os títulos acadêmicos obtidos tornam-se, como a propriedade de terras, fonte de status na sociedade Colonial.

\section{0 tipo de educação oferecido à s elites}

A Educação das Elites, ministrada pelas Instituições Educacionais da Companhia de Loyola, caracterizava-se pelo ensino das Ciências Humanas, das Letras, da Filosofia e da Teologia, num clima de rigidez e de ascetismo 
intelectual e disciplinar, conforme Bourdieu (1989) e senso de humanismo e universalismo.

Essa abordagem educacional não considerava, sequer, a realidade social e as necessidades da maioria do povo. Logo, uma educação sem nenhuma repercussão social, conservadora do status quo. A educação dada pelos jesuítas era mais e mais aceita, "porque ela não perturbava a estrutura em vigor, subordinando-se aos imperativos do meio social, (...). (SODRÉ, 1970)

Para a formação do clero, os jesuítas, visando também a aumentar o contingente da Companhia, organizaram os primeiros cursos superiores no Brasil: os de Teologia. Os outros membros da elite que quisessem completar seus estudos de formação em Humanidades iriam às Universidades européias, sobretudo à de Coimbra. ${ }^{9}$

\section{Ex pulsão dos jesuítas do Reino de Portugal}

Os Jesuítas se desenvolveram na Igreja do mundo inteiro, muito rapidamente, e ajudaram-na a se renovar após os acontecimentos da Reforma Protestante. Este desenvolvimento deu-se, também, em Portugal, mas sobretudo na sua colônia brasileira. Fundaram escolas e cursos superiores para a elite, catequizaram e estruturaram os indígenas; ocuparam-se com o recrutamento e a formação do clero e desenvolveram, também, métodos de ensino etc. Cada vez mais sua presença e "força" se faziam sentir.

Depois do Feudalismo, houve na História da Civilização Ocidental duas etapas econômicas bem assinaladas: o mercantilismo e a industrialização. Na primeira etapa, por causa de seu poder mańtimo e colonial, nos séculos XV e XVI, até a metade do XVII, Portugal estava bem colocado em relação à economia mundial.

Começou a perder seu poder e influência no momento da industrialização. Logo sua economia tornou-se subordinada às grandes potências nesse domínio, especialmente à Inglaterra. Portugal assina com esta nação o tratado de Methen, ${ }^{10}$ comprometendo seriamente a economia portuguesa, criando uma forte dependência com a Inglaterra. Este processo de degradação econômica, começado durante a dominação espanhola ${ }^{11}$ e acentuado com os esforços de Portugal para dela se libertar, acentuou-se no momento da queda da exploração mineral no Brasil.

Sebastião José de Carvalho e Melo, ministro do Rei Dom José I, conhecido como o Marquês de Pombal, estabeleceu, então, um programa para voltar à situação anterior em Portugal. Para isso experimentou:

- centralizar o poder real;

- promover o ensino e a cultura;

- retomar o desenvolvimento econômico; 
Para conseguir, era preciso reduzir o poder dos Jesuítas em Portugal. Um dos golpes mais duros foi a perseguição religiosa desencadeada contra os Jesuítas, seja em Portugal, seja no Brasil.

Na Metrópole, tanto quanto na Colônia, entre os exploradores dos indígenas, os donatários das Capitanias, o clero etc. havia uma grande indisposição e descontentamento contra os Jesuítas. Eles eram considerados como detentores do poder econômico e formadores das novas gerações para seus interesses e não para os interesses do país. (RIBEIRO, 1989)

A expulsão da Companhia de Jesus de Portugal e do Brasil foi executada, por ordem do Marquês de Pombal, em 1759. Há uma discordância quanto ao número de estabelecimentos que os Jesuítas possuíam naquela época. "Para Tito Lívio Ferreira, eram vinte Colégios, doze Seminários, um Colégio e um recolhimento Feminino. Para Fernando Azevedo, eram 36 residências, 36 missões, 17 colégios e seminários, sem contar os seminários menores e as escolas de ler e escrever (...)". (RIBEIRO, 1989)

Pode-se dizer que com a expulsão dos jesuítas termina a primeira etapa da Educação Católica no Brasil e, até mesmo, da Educação Brasileira.

\section{A era pombalina e o ensino público}

Pelas razões expostas acima, após a expulsão dos jesuítas do Brasil, a escola pública nasce pela alocação de recursos financeiros e de pessoal para este fim. A intenção de Pombal era, por meio dos agentes educativos pagos e controlados pelo Estado, formar as elites, os quadros administrativos e políticos, e não mais uma educação que favorecesse os interesses da Igreja e outros. Ele procura fortalecer o centralismo próprio do despotismo que visa a instalar.

Apesar dos elementos que se poderiam considerar como negativos na pedagogia dos jesuítas, como: a subordinação absoluta da pedagogia à Escolástica, segundo o modelo do "Ratio Studiorum", contrário à moderna filosofia cartesiana e às novas ciências físico-naturais, havia elementos de resistência à hegemonia do Estado. Por exemplo:

- uma organização centralizada na educação fora do controle do Estado;

- uma obediência a Roma (defesa da autonomia da Igreja);

- uma oposição à escravidão dos indígenas, organizando-os por meio das Missões (modelo sóciopolítico-econômico inovador e autônomo). (ESRAN, 1989)

A relação entre a autonomia institucional e a educação caracterizava bem a força da resistência da Escola Católica no Brasil Colônia. 
Logo após a expulsão dos jesuítas, o governo começou a reorganizar o ensino e, ao mesmo tempo, estabelecer seus novos objetivos. Mas foi necessária ao menos uma década ao governo de Pombal para reorganizar o ensino. Quanto à definição dos objetivos, jamais o conseguiu plenamente. Sob o aspecto de organização, em 1759, pelo decreto de 28 de junho, ele criava a Direção Geral, uma espécie de "Ministério da Educação" para a Colônia, para se encarregar de toda a estrutura educacional, no Brasil. A intenção era modernizar a educação da elite colonial para que ela pudesse servir melhor aos interesses e projetos de exploração da Metrópole Portuguesa.

Esse Diretor Geral, responsável por todo o ensino público, o único naquele momento, levou mais de dez anos para criar as estruturas básicas que permitiram pôr em andamento o sistema escolar.

Entre as mudanças mais significativas da organização, citamos aqui: os concursos de admissão ao ensino; a expedição de licença para ensinar; a obrigação de ter uma autorização para abertura das escolas; a definição dos livros escolares; a conversão do Curso de Humanidades criado pelos jesuítas, em Classes Reais (classes separadas em várias disciplinas).

Entretanto, os objetivos propostos para um ensino mais moderno, conforme os modelos das grandes potências européias, deviam levar um maior número de jovens às universidades; aprofundar a língua materna (o português) em vez do latim e do grego; dar um ensino de natureza científica (física, matemática etc.); ministrar um ensino prático.

Estes objetivos não foram alcançados. Diversos pesquisadores consultados são unânimes em afirmar que as mudanças educacionais não ultrapassaram o nível político e organizacional. Limitaram-se à introdução de novos métodos, da laicidade no ensino, de novos livros, sem falar da responsabilidade direta do Estado sobre o conjunto da Educação, não conseguindo alcançar os objetivos pedagógicos propriamente ditos. Alguns autores chegam mesmo a falar de retrocesso pedagógico.

A verdade é que a educação dos jesuítas (as humanidades, 0 academicismo, o aristocracismo) foi preservada in totum pelos professores, seja do clero secular, seja leigos formados nos colégios e/ou seminários da Companhia de Jesus. Alguns entre os historiadores da educação brasileira afirmam traços destes elementos que perduram até nossos dias. O erro do governo foi o de negligenciar a formação de um professorado capaz de responder aos seus objetivos.

Mesclado a todos esses fatores de ordem educacional, houve outros, de caráter econômico, social, político e religioso. Entre estes, recordemo-nos da perseguição obstinada contra a Igreja ligada a Roma, em conseqüência da qual houve uma redução do número de bispos e de padres; a Igreja no Brasil afastou-se do Papa; e, ao mesmo tempo, doutrinas como o jansenismo e 0 
regalismo que grassaram por toda parte. Os bispos e os padres são, então, todos nomeados pelo Estado.

Depois do Marquês de Pombal, durante o reinado de D. Maria I (1777-1792), as "Reformas Pombalinas", que intentaram reconduzir Portugal ao grupo das grandes potências do mundo ocidental daquela época, começaram a ser atenuadas. A Rainha favoreceu um movimento para retornar-se a muitas coisas que existiam antes.

Para não citar senão um exemplo, a "Igreja brasileira" pôde criar algumas fundações educacionais bastante importantes, entre as quais citamos o Seminário de Olinda, que foi a uma certa época da história do Brasil um dos centros educativos de maior destaque. Fundado em 1880 por Monsenhor José Joaquim de Azevedo Coutinho, formado em Coimbra no novo espírito, converteu-se num Centro freqüentado por uma parte do clero e dos intelectuais progressistas, partidários da independência da Colônia.

Esse período extremamente curto, de um meio século (1759-1808), viu o nascimento do Ensino público no Brasil, que não mais cessou de crescer, apesar de avanços e recuos sofridos no período em que a Coroa instalou-se no Brasil.

\section{A coroa no Brasil}

Não há fato histórico que não tenha tido por causa um outro fato, intencional ou não. A história é também causalidade. Foi justamente o expansionismo francês, sob o reinado de Napoleão, que conduziu o Brasil aos acontecimentos decisivos que desviaram os rumos de sua história, em relação à marcha da história das vizinhas colônias hispano-americanas e das colônias portuguesas da África e da Ásia.

Em 1807, o exército de Napoleão invadiu Portugal, este sempre aliado da Inglaterra, inimiga da França, com a qual estava em guerra. Por causa disto o Regente Dom João VI, que governava desde 1792, e a Corte foram obrigados a fugir para o Brasil, no começo do ano de 1808, aqui ficando até 1821. Apesar da brevidade deste período, bastante excepcional para o governo de uma Colônia, ele foi de uma extrema riqueza, sob todos os pontos de vista, para o desenvolvimento do Brasil. E o foi, também, para a educação em nosso país.

A instalação do governo português no Brasil introduziu aqui o que era necessário, seja para o cumprimento de suas atividades administrativas, seja para a vida cultural e educativa, sobretudo quando este governo está no centro de um Reino, com as necessidades próprias à vida de uma Corte.

Na esfera educacional, que é o que aqui nos interessa, podemos apresentar como aspectos mais relevantes: 
- A instalação, por decretos reais, das instituições de ensino superior, além da teologia; Ribeiro (1989) elucida o que aqui chamamos "curso superior": “(...), a expressão "curso" não dá a idéia precisa, uma vez que, em verdade, muitos correspondiam a aulas, como as de economia, anatomia, etc.(...) a organização isolada (não-universitária) e a preocupação basicamente profissionalizante.

- A criação de vários organismos de caráter cultural e científico;

- No domínio da arte, a Missão Cultural Francesa teve uma importância bastante grande. Era, como se sabe, constituída de um grupo de vários pintores, escultores, arquitetos e técnicos de diversos ofícios. A "Missão" chegou ao Rio em 1816. Em seguida, criou-se, em 1820, a Academia Real de Desenho, Pintura, Escultura e Arquitetura Civil.

Notemos que tudo isso foi instituído em função da vida cultural e educacional da Corte. Para a formação superior e para alguns ofícios técnicos, era necessário desenvolver a infra-estrutura de uma cidade, que veio a ser sede do Vice-Reino do Brasil e Algarves, condição à qual a Colônia fora elevada desde a chegada de Dom João VI, com todas as prerrogativas daí decorrentes. Entretanto, para o ensino primário e secundário não se criou grande coisa, ficando este setor no abandono.

Evidentemente, o Ensino Católico não constituiu uma exceção à regra. Desde a expulsão dos jesuítas (1759), não havia senão alguns Seminários, Internatos para moças e pequenas Escolas Paroquiais foram fundadas. Foi 0 período de maior enfraquecimento da Igreja no panorama nacional. A Igreja, por sua vez, estava cada vez mais abandonada à própria sorte. $\mathrm{O}$ número de padres era cada vez menor e havia uma forte dependência com o governo civil.

\section{A Coroa brasileira e o ensino privado}

A partir da Revolução Constitucionalista de 1820 na cidade do Porto, em Portugal, ainda sob a influência da Revolução Francesa, que queria reduzir o poder Real, o contexto político em Portugal exigiu a volta de Dom João VI e de toda a Corte. O Rei deixou no Brasil seu filho Dom Pedro para se ocupar do governo local.

A Corte, de volta a Lisboa, fez pressão sobre o governo do Brasil para que este país voltasse à sua antiga condição de colônia, tirando-lhe o título de Vice-Reino e fechando-lhe as portas que haviam sido abertas em 1808 ao comércio exterior. Concretamente, isso implicava o fechamento de diversas Instituições e, de novo, a monopolização do comércio pela Metrópole.

Com o apoio da classe dominante colonial, e também das outras camadas sociais, para não ceder às exigências de Portugal e dar autonomia ao 
A escola católica, uma história de serviço ao povo e à nação brasileira

Brasil, Dom Pedro o proclamou independente. Em seguida à derrota dos pontos de resistência militar, as nações estrangeiras e o próprio Portugal reconheceram a nova Nação. O Brasil tornou-se um Império.

Essa autonomia política não levou a mudanças significativas para 0 país, nem mesmo no campo educacional, nem na Igreja. O sistema monárquico foi preservado pela presença do Imperador. A Corte, não existindo no novo Império, do mesmo modo que outrora, foi, como se sabe, substituída pelas elites econômicas e intelectuais. Considere-se a independência como "simples transferência de poderes dentro de uma mesma classe, (...) entregaria a direção da nova ação aos proprietários de terras, de engenhos e aos letrados" (COSTA, 1989). Estes últimos, em particular os intelectuais (e entre eles os padres ligados ao Estado), ocuparam postos da administração pública.

Em 1824, o Brasil promulga sua primeira Constituição. Esta Constituição consolida o estado sociopolítico-econômico que existia no tempo da Colônia, inclusive no que concernia à Igreja e às suas relações com o Estado. A relação Estado-Igreja permanece a mesma. Embora tendo reconhecido a Religião Católica Romana como religião oficial do Brasil, as outras estando excluídas, não se restabelece nenhuma ligação com Roma, e mantém-se sempre o "Padroado".

Esta posição manteve os limites impostos à Igreja no que diz respeito à Educação, mesmo nos Seminários. A perseguição contra as Congregações Religiosas e o Clero estrangeiro e oposição a todas as intervenções de Roma foram mantidas. $\mathrm{O}$ antijesuitismo continuou. Nada de importante neste sentido será mudado durante o regime Imperial.

Sempre houve um certo número de padres ligados ao Estado e opostos a Roma, desde que a Constituição deu ao Imperador o máximo de autoridade sobre a Igreja no Brasil, inclusive para a nomeação dos bispos.

Quanto à Educação, a nova Constituição pensou, pela primeira vez, inspirada no modelo da Constituição francesa de 1791, na criação de um Sistema Nacional de Educação, propondo escolas primárias para todas as cidades, colégios e liceus em cada capital e ensino superior nas grandes cidades. Mas, finalmente, o texto constitucional aprovado somente estabeleceu que o ensino primário seria gratuito e obrigatónio para todos os cidadãos, e que Colégios e Faculdades seriam criadas.

Portanto, a Constituição não fez senão consolidar a realidade educativa já existente, acrescentando nela somente o ensino primário obrigatório para todos. A Igreja Católica, por seu lado, ficou limitada a um mínimo de expressão educacional (de 1759 até a segunda metade do XIX século).

Entretanto, as dificuldades econômicas causadas pelo aumento do consumo e, em conseqüência, da importação; pela economia essencialmente agrária; pelo endividamento do país (começaram-se a empréstimos exteriores) e pelo nascimento do aparelho burocrático do Estado; reduziram os recursos 
necessários para organizar a educação, mesmo no nível primário. Exceção feita de alguns cursos superiores criados em função das necessidades das elites e das do Estado, para formar novos quadros da administração pública. Assinalem-se as Faculdades de Direito, até então existentes: Rio de Janeiro (1825), São Paulo e Recife (1827). Essas faculdades sofreram um grande desenvolvimento em relação aos outros níveis de ensino.

No dia 07 de abril de 1831, Dom Pedro I abdica em favor de seu filho e vai para Portugal. Durante a Regência decretou-se um Ato Adicional à Constituição (1834) que influenciará de maneira significativa na evolução da Educação no Brasil. Esta influência se faz sentir, ainda hoje, até na Escola Católica, como veremos mais adiante.

A nova legislação descentralizou a direção da educação. O ensino primário, bem como o secundário, estavam até aquele momento sob a exclusiva responsabilidade do governo de cada Província. O governo central tinha a responsabilidade de todo ensino superior existente ou a ser criado.

A desarticulação entre os dois sistemas (sistema primário e secundário) foi instalada. Era o ensino superior que organizava o ensino secundário como unicamente preparatório às Faculdades. Em função dos exames de admissão estabelecidos pelas Instituições de ensino superior, todas as escolas do Brasil criaram seu currículo e organizaram sua estrutura.

Não havia nenhum outro interesse para as elites a não ser a admissão ao ensino superior. A realidade escravagista, presente no mundo do trabalho, contribuiu para a estagnação no domínio do ensino secundário técnico-prático-científico. Em conseqüência, ele permaneceu livresco, o que afastou dele as outras camadas sociais menos favorecidas. Uma herança antiga que se guarda até hoje na educação no Brasil.

Alguns grandes Colégios foram também criados e concebidos como estabelecimentos modelos para a educação nacional, capazes de habilitar para os exames superiores, bem como escolas normais criadas para a formação de professores primários: Niterói (1835), Bahia (1836), Ceará (1845) e São Paulo (1846). O mais célebre foi o Colégio Dom Pedro II do Rio de Janeiro, capital do Brasil desde 1776, o único criado pelo governo central.

A lei de 1834 teve uma segunda conseqüência, também muito importante para a educação no Brasil, sobretudo para o desenvolvimento do ensino católico privado. A ausência de recursos das "Províncias" para organizar seu próprio ensino, público e gratuito, especialmente em nível secundário, abriu espaço para que a iniciativa privada assumisse tal tarefa. Neste contexto, a Igreja pode, pouco a pouco, conforme as circunstâncias em cada Província, retomar seu lugar no ensino. Nascia, então, a escola privada, financiada diretamente pelos pais dos alunos. Evidentemente, o ensino "popular", para as camadas sociais que não tinham a possibilidade de pagar sua escola, mesmo 0 primário, continuou abandonado em um primeiro momento. 
A realidade era, então:

- ensino público, primário e gratuito em estado de abandono;

- e o ensino secundário, privado e pago, mantido pelas elites e para elas, em função de seu acesso aos Estabelecimentos Superiores.

A partir desse momento, mais e mais as escolas privadas secundárias, à medida que o acesso ao ensino superior se torna possível, tornam-se escolas a serviço das elites, que tinham em vista ver seus filhos, o mais cedo possível, incorporados à "classe dos homens letrados", reconhecidos como habilitados para preencher as funções sociais que tornam possível a manutenção do padrão de vida, do status, e de subir na hierarquia administrativapública.

\section{A igreja e a sua escola na segunda metade do século XIX}

No segundo Império, não mais favorável à Igreja do que antes, as formas de controle pelo "Padroado" permaneceram as mesmas. Um grupo de padres e alguns bispos começaram a se preocupar em fazer a Igreja crescer e organizar melhor suas ligações com Roma. ${ }^{12}$ Este movimento não terá pleno êxito senão depois da queda do Império.

No domínio econômico, esta parte do século XIX, por volta de 1850, foi marcada no Brasil pela expansão da produção e da exportação do café. Houve um verdadeiro crescimento econômico, que se traduziu por um aumento dos rendimentos das camadas privilegiadas da sociedade, sem todavia se traduzir por uma melhoria na distribuição dos bens nas demais camadas sociais.

No tocante à Educação, em 1854 tomaram-se, entre outras, as seguintes medidas: a criação, no Rio de Janeiro, da Inspetoria Geral da Instrução encarregada de controlar o ensino primário e secundário, público e privado, a fixação de normas para regulamentar a liberdade do ensino, e o estabelecimento de um sistema de formação dos professores primários.

Apesar de tudo isto, não se concedeu nenhuma atenção especial à escola pública. Por outro lado, e a título de suplência, a escola privada ganhou terreno, estimulada pelas classes socialmente privilegiadas, não somente por que havia uma má escola pública, mas também por razões de outra natureza.

Maria Luisa Santos Ribeiro comenta a educação nesta época da seguinte forma:

(...) numa organização econômico-político-social como a do BrasilImpério, as medidas especialmente relacionadas à escola acabavam por depender marcadamente da boa vontade das pessoas. Pessoas estas que atuam dentro e nos limites da estrutura educacional existente. As modificações propostas são superficiais por serem pessoas pertencentes à camada privilegiada, sem razões fundamentais para interessar-se pela transformação da estru- 
tura social geral e educacional, especificamente. São superficiais, também, pelo tipo de formação superior recebida, que oferece uma interpretação da realidade, fruto desta perspectiva de privilégios a serem conservados. (...) É assim que os formados no Brasil tinham conhecimento e discutiam as últimas novidades que poderiam ser consumidas através da literatura predominantemente européia. Este tipo de atividade escolar envolve um gosto acentuado pela palavra e limita as possibilidades de concretização das idéias. Luiz Agassiz, após uma visita ao Brasil, declara: "nenhum país tem mais oradores nem melhor programa; a prática, entretanto, é o que falta completamente". (RIBEIRO, 1989)

Desde 1834 não faltaram novas medidas na esfera educacional, sem no entanto surtirem os efeitos desejados. A iniciativa privada não parou de crescer à medida que a classe média também aumentava, e fazia pressão para a abertura de escolas, como meio de ascender socialmente pela legitimação oferecida pelo ensino superior. Quase toda a população feminina era, então, analfabeta. As poucas exceções haviam freqüentado somente a escola primária. Pouco a pouco a iniciativa privada, sobretudo através das escolas das Irmãs, começaram a abrir cursos secundários para moças.

Neste contexto, a Escola Católica começou a ocupar um lugar de destaque no cenário educacional brasileiro com a fundação de diversos estabelecimentos. Um caso típico foi o do Colégio do Caraça, a escola dos padres Lazaristas franceses fundada em 1856. ${ }^{13}$ Na Igreja, o grupo pró Roma, partidário do fim do "Padroado", começou a entrever a possibilidade de uma autonomia política e do papel que poderia exercer a Escola Católica em um futuro que não estava muito distante. Ela começa, então, a se preparar para viver 0 processo que se denominou de "Romanização", um conjunto de medidas empreendidas para restabelecer a vinculação à Santa Sé, criando sua própria organização interna: formação de quadros religiosos e leigos, nomeação dos bispos e criação de dioceses, criar fontes de renda, fundação de instituições, aquisição de propriedades e patrimônios diversos etc.

Os ideais liberais, anticlericais, positivistas e republicanos tomavam cada vez mais força no seio da sociedade brasileira. Nesta conjuntura, em 18 de abril de 1879, foi decretada uma reforma do ensino que ficou conhecida pelo nome de seu principal articulador, Leôncio de Carvalho. Entre as diferentes medidas para a Escola Católica, a mais importante foi a ampliação dos parâmetros para a liberdade de ensino. Em função desta medida tornou-se possível a manifestação de outras tendências pedagógicas e tomou livre o credo religioso dos alunos.

Foi o nascimento do pluralismo educacional no Brasil, já no final do seu quarto século de história. A medida oportunizou que positivistas e protestantes abrissem algumas escolas. Às vésperas da proclamação da República em 1898 havia no Brasil somente 250.000 alunos para uma população de 14 milhões de habitantes. 


\section{A velha república e a escola livre}

Consideramos esse período histórico da Educação Católica como um dos mais importantes na História do Brasil, senão o mais importante. É no quadro desse período, chamado Velha República ou Primeira República (18891930), que se deram relevantes mudanças políticas. A nova Constituição é promulgada em 1891, estabelecendo o regime presidencial de sistema federativo.

Como conseqüência natural do sistema federativo, a descentralização concedida ao ensino em 1834, cujos efeitos já foram assinaladas anteriormente, foi definitivamente adotada no sistema educativo brasileiro. Assim, a criação e a manutenção do ensino superior passou para a responsabilidade do governo federal. Ficava a cargo de cada unidade da Federação a obrigação de prover as despesas do ensino secundário e de assumir a plena responsabilidade pelo primário.

Era, portanto, a consagração do sistema dual de ensino, que se vinha mantendo desde o Império. Era também uma forma de oficialização da distância que se mostrava, na prática, entre a educação da classe dominante (escolas secundárias acadêmicas e escolas superiores) e a educação do povo (escola primária e escola profissional). ${ }^{14}$ Refletia essa situação uma dualidade que era o próprio retrato da organização social brasileira. O que, entretanto, não ocorria ao sistema assim consagrado era o fato de a nova sociedade brasileira, que despontava com a República, já ser mais complexa do que a anterior sociedade escravocrata. Havia vários estratos sociais emergentes. $\mathrm{O}$ povo já não abrangia apenas a massa homogênea dos agregados das fazendas e dos pequenos artífices e comerciantes da zona urbana (...) A pressão não tardaria, pois, a provocar a ruptura das limitações impostas pela Constituição. E a instituição da escola, calcada no princípio da dualidade social, iria aos poucos ter seus alicerces comprometidos pelo crescimento e complexificação dessas camadas. (ROMANELU, 1989)

No que diz respeito à História do Catolicismo no Brasil e à sua Escola, o fim do "Padroado" foi fundamental. O governo provisório do Marechal Deodoro da Fonseca (1889-1891) promulgou a separação oficial e constitucional entre a Igreja e o Estado.

A Constituição de 1891 estabelecia:

- reconhecer o direito de existir para todas as Religiões;

- garantir a liberdade de culto;

- suprimir a subvenção ao clero;

- proibir aos padres e aos religiosos o exercício dos direitos políti-

cos;

Revista Diálogo Educacional, Curitiba, v. 3, n.7, p. 37-62, set./dez. 2002. 
- reconhecer somente os casamentos civis;

- ceder a administração dos cemitérios às municipalidades;

- eliminar o ensino religioso do Currículo escolar oficial;

- suprimir a ajuda financeira às Escolas Católicas.

A Igreja, pelo menos uma parte do episcopado e do clero, que procurou se libertar da tutela do Estado, ficou surpresa ao se ver excluída tão abruptamente do poder público e político, e de ser colocada em igualdade com todas as outras religiões. Isso representava uma razoável perda de seus privilégios. Era necessário à Igreja reconquistar seu status, sua influência sobre o Estado e a Sociedade, e ocupar-se ao mesmo tempo de sua organização e de renovar suas ligações com o Papa e a Santa Sé. Em 1889 a Igreja no Brasil, em conseqüência do sistema anterior, contava apenas com 13 bispos e 700 padres (clero geralmente mal formado e submetido ao estado) para os 14 milhões de habitantes.

A fim de concretizar este propósito e obter o reconhecimento de seu caráter majoritário como religião do povo, com o apoio do Vaticano, a Igreja, no Brasil, tomou, entre outras, as seguintes medidas: multiplicação das dioceses e arquidioceses, ${ }^{15}$ abertura de seminários, ordenação de padres e bispos, (re)fundação de conventos e de comunidades religiosas, criação de numerosas Escolas Católicas etc. Nesta empreitada considerável, a Escola Católica teve um lugar muito importante.

A forte influência positivista no movimento republicano se fez sentir na reforma que tinha por finalidade sintonizar a educação aos seus ideais. As proposições básicas eram a laicização, a gratuidade e a preponderância das disciplinas científicas, em ruptura ao modelo humanista clássico; numa palavra, uma escola para o cidadão, acessível a todos e que prepara para a vida.

Essa reforma de ensino, decretada em 1890, sob a coordenação de Benjamin Constant, foi um fracasso. A maior parte ficou letra morta. Benjamin Constant e sua equipe perderam de vista as variáveis econômicas, como a falta de recursos e de infra-estrutura, assim como também os obstáculos políticos, a falta de apoio das elites que não queriam prejudicar a formação de seus filhos, segundo o modelo tradicional, e que desejavam proteger seu status quo.

É importante recordar que, após o êxito da proclamação da República, que preserva os interesses das elites, os intelectuais positivistas, os militares e a classe média foram marginalizados pelas elites. Eles já tinham desempenhado seu papel. Um bom exemplo foi a queda do Floriano Peixoto, em 1894.

As outras reformas que se seguiram nada conseguiram, a grosso modo, pelas mesmas causas. Nenhuma destas reformas de ensino, apesar de suas diferenças, às vezes contraditórias, modificou de maneira significativa o sistema escolar. A despeito de seus méritos, essas reformas sempre ignoraram os 
conflitos socioeconômico-políticos. "A troca do regime político não foi seguida de uma renovação das estruturas educacionais e pedagógicas" (AZEVEDO, 1958). Pelo contrário, de 1889 a 1920, o analfabetismo aumentou em número absoluto e proporcionalmente ao número dos alfabetizados.

O esforço para acompanhar o crescimento demográfico, com o aumento do número de escolas, significou a preocupação do governo com 0 ensino primário. A rede privada, especialmente os estabelecimentos católicos, ocuparam-se sobretudo do ensino secundário, perdendo, assim, de vista, as necessidades dos segmentos populares. As estatísticas disponíveis no período de 1907 a 1912 registraram mesmo uma queda nas matrículas para o ensino secundário. A “(...) insuficiência da iniciativa oficial faz com que a este nível (secundário) continue ocorrendo um outro ponto de estrangulamento na organização escolar brasileira, de tal maneira que a elitização se mantém como uma característica marcante". (RIBEIRO, 1989)

É preciso notar, também, que o fato de serem as escolas privadas e pagas, no caso do ensino secundário, restringiu aos alunos das camadas privilegiadas e médias da sociedade, minoria da população. Para a classe média era meio privilegiado de ascender socialmente.

O fenômeno, do qual já falamos, isto é, a corrida dos mais privilegiados para o ensino superior, através da escola secundária, acentuou-se ainda mais. Como disse Leôncio Basbaum: "éramos um país de doutores e de analfabetos". (BASBAUM, 1962)

\section{A igreja e a educação sob a primeira república}

Como já foi dito, a Igreja empenhou todos os esforços para recobrar sua influência na sociedade. Para isso, esforçou-se, sobretudo, em aumentar seus efetivos. Paralelamente ao recrutamento e à formação de um clero autóctone, muitos padres, religiosos e religiosas estrangeiros, pertencendo a diversas congregações e nacionalidades diferentes, chegaram ao Brasil. ${ }^{17}$ Isso também fez parte do processo de "Romanização" da Igreja no Brasil.

Muitos desses religiosos pertencendo a Congregações docentes vieram para o Brasil. Houve, sem dúvida, relação entre este fato e a expulsão dos religiosos educadores da França por ocasião da laicização do ensino naquele país por ordem do Ministro Combes. Um grande número de religiosos, sobretudo Irmãos e Irmãs Educadoras, cujo grande número de suas Congregações haviam sido fundadas na França desde o século XVII vieram para o Brasil. É conhecida a carta de Pio X, de 23 de abril de 1905, ao Superior Geral dos Lassalistas, a Congregação educadora mais numerosa naquele momento na França, a respeito de certos desvios em relação às obrigações da Vida Religiosa dada a condição de "clandestinidade" em que caíram, donde era preferível 
partir para o estrangeiro do que continuar na França e deixarem o estado religioso. O mesmo se pode inferir de um trecho da biografia escrita por Faustino et al. (1987, p. 26) do Irmão Afonso, Irmão Marista francês, fundador da PUCRS:

Chegou ao nosso conhecimento que nas escolas de religiosos na França se generalizou entre eles a opinião de dar a primazia à formação cultural e profissional e de deixar em segundo plano a formação religiosa. Nós não queremos de forma alguma que esta opinião prevaleça em nosso Instituto. A Vida Religiosa está acima da vida comum. E mais, si seu Instituto assume obrigações graves em relação ao próximo de ensinar, muito mais graves são as obrigações assumidas diante de Deus...

As fundações de escolas a pedido dos Bispos, multiplicam-se extraordinariamente e em grande rapidez. No contexto da falta de recursos humanos e materiais do Estado para a Educação, a Escola Particular Católica ocupa os espaços vazios, sobretudo no ensino secundário.

Ao lado disso, havia sempre a vontade de recuperação de uma posição de influência e de poder social que a Igreja perdera quando da proclamação da República. Então, ela se preocupou especialmente com a formação das elites, ${ }^{17}$ uma vez que suas escolas se tomaram caras para a maioria da população. ${ }^{18}$

De fato, quase todo ensino secundário, e uma boa parte do primário e do superior, estarão logo nas mãos da Igreja. Em 1889, havia 292 escolas secundárias no Brasil; em 1930 o número atingirá 1.130 escolas com 83.190 alunos, das quais 1.090 são particulares, com 73.995 alunos. (HADDAD, 1981) O que significa mais de $95 \%$.

Estas escolas “(...) estavam ao serviço da classe privilegiada, pela formação, nas escolas secundárias, dos filhos do empresariado que assumiriam 0 poder e das moças, através das escolas das Irmãs, que refleteriam nos seus lares a educação cristã recebida. Sulpício apud Rieiro (1981), "No Colégio Diocesano São José (...) no Rio de Janeiro, mais que em outros Colégios figuravam ilustres professores já lá estavam antes da chegada dos Irmãos em 1902 (...). Eram eles o Doutor Carlos de Laet, professor de grego e literatura, o Doutor Carlos Murphy, de inglês e alemão, e o Doutor Alexandre Max Kitzinger, professor de francês. Eles foram ali mantidos para ensinar as disciplinas de sua especialidade, (...). O leitor perguntará qual era a razão de ser incluídas entre as disciplinas do Colégio São José o grego, o alemão, a esgrima. (...) Somente as pessoas ricas tinham acesso aos estudos mais avançados feitos à Metrópole. (...) Vê-se que o currículo do Colégio São José, antigo Seminánio, se inspirava, até os primeiros anos da República, no modelo europeu", dando uma cultura acima da realidade social e de caráter elitista, "no Colégio Diocesano São José (...) no Rio de Janeiro, mais que em outros Colégios figuravam ilustres professores já lá estavam antes da chegada dos Irmãos em 1902 (...). Eram eles o Doutor Carlos de Laet, professor de 
A escola católica, uma história de serviço ao povo e à nação brasileira

grego e literatura, o Doutor Carlos Murphy, de inglês e alemão, e o Doutor Alexandre Max Kitzinger, professor de francês. Eles foram ali mantidos para ensinar as disciplinas de sua especialidade, (...). O leitor perguntará qual era a razão de ser incluídas entre as disciplinas do Colégio São José o grego, 0 alemão, a esgrima. (...) Somente as pessoas ricas tinham acesso aos estudos mais avançados feitos à Metrópole. (...) Vê-se que o currículo do Colégio São José, antigo Seminário, se inspirava, até os primeiros anos da República, n o modelo europeu, Sulpício apud Ribeiro (1981), procurava-se manter um tipo de influência independente do poder o Estado, que garantisse uma nação formalmente católica, mas de um conteúdo evangélico fraco no meio social.

O ensino católico foi considerado pelas elites como de qualidade excelente, por causa da dedicação dos religiosos e, por sua vez, a Igreja estava convencida em manter sua influência formando os futuros quadros dirigentes do país. Portanto, a Escola Católica servia, ao mesmo tempo, aos interesses do Estado, das classes dominantes e médias e aos seus próprios. $\mathrm{O}$ que não significa que não fossem também abundantes as iniciativas educacionais da Igreja em favor dos menos favorecidos, especialmente os orfanatos, as escolas populares e as noturnas e as de formação profissionalizante.

Em 1925, Dom Sebastião Leme da Silveira Cintra (1882-1942), Cardeal Arcebispo do Rio de Janeiro, obteve uma emenda na Constituição da República, que reconheceu como religião oficial no Brasil a religião católica, além de outras vantagens.

A chegada maciça de Congregações Religiosas e a fundação de numerosas Escolas Católicas no Brasil depois da Proclamação da República, que se declarara, entretanto, laica e havia rompido as ligações com a Igreja, parece paradoxal.

\section{A ditadura do estado novo e novas conquistas}

O descontentamento provocado pela Velha República provocou um movimento militar que terminou com a queda do Presidente Washington Luiz. O período de 1930 a 1945 teve como Chefe de Estado Getúlio Vargas, que governou como ditador a partir de 1937. Foi o Cardeal Leme que, a pedido de Getúlio, conseguiu convencer Washington Luiz a se demitir. Esse fato contribuiu para restituir à Igreja, na pessoa do Cardeal, certa influência.

Entre as decisões governamentais obtidas pela Igreja, várias diziam respeito à Educação Católica. Já no dia 30 de abril de 1931 decretou-se a volta do ensino religioso à Escola Pública. A nova Constituição de 1934 proclamava a defesa da indissolubilidade matrimonial, o ensino religioso facultativo nas escolas públicas, a assistência religiosa regulamentar ao Exército, aos hospitais e às prisões, a liberdade de organização de um sindicato para o Educação Católica, a proibição do divórcio, a ajuda financeira às Escolas Católicas etc. 
Esse período não representou grandes mudanças para a realidade prática da Escola Católica, mas foi, no nível ideológico, provavelmente o mais fértil. Para a Igreja significou o surgimento de uma nova intelectualidade católica leiga no Brasil a exemplo do que ocorrera na França (Léon Bloy, Charles Peguy, Jacques Maritain, Georges Bernanos etc). No Brasil, duas pessoas estiveram à frente deste movimento análogo: Jackson de Figueiredo e Alceu de Amoroso Lima. A ação educativa da Igreja nesse período foi orientada pela encíclica Divini Illius Magister de Pio XI, publicada a 31 de dezembro de 1929.

No mesmo contexto surgiram a LEC (Liga Eleitoral Católica) e os grupos da Ação Católica Internacional, com a JEC (Juventude Estudantil Católica) e a JUC (Juventude Universitária Católica) desempenhando um grande papel na vida política do país nos anos de 50 e 60 .

Para a Educação Nacional, foi neste período que surgiu a Escola Nova, com uma geração de educadores, de caráter liberal, com destaque para Anísio Teixeira, que se empenhavam na luta por um ensino público de qualidade e laico em oposição à Escola Particular, especialmente a confessional. Foi a época de grandes conflitos entre católicos e liberais, e de luta em favor da escola leiga, como já acontecera em outros países do mundo. ${ }^{19}$

O golpe de Estado de 1945 depôs o ditador. Há uma abertura democrática. Novas formas de organização sócio-política são adotadas. Entretanto, a Constituição de 1946 manteve todos os direitos adquiridos anteriormente pela Igreja. Nessa época, para responder a todos estes desafios foi fundada, em novembro de 1945, a Associação de Educação Católica do Brasil - AEC, seguida, em janeiro de 1952, da fundação da ABESC - Associação Brasileira de Ensino Superior Católico.

\section{As últimas décadas e os desafios do futuro}

Por causa do crescimento demográfico da classe média e da rede pública do ensino secundário, a Igreja vai perder, a partir dos anos 50, em porcentagem, a maioria no ensino secundánio. Suas escolas continuarão a atuar decisivamente na formação das lideranças nacionais. Até a década de 60, o expansionismo da Escola Católica, começado no fim do último século, prosseguiu.

A partir dos anos 70, com as transformações introduzidas pelo Concílio Vaticano II e aprofundadas em Medellin e Puebla para o contexto da América Latina, com os seus reflexos sobre a Vida Religiosa Educadora e a pastoral orgânica da Igreja e uma clara e decisiva opção pelos pobre, a realidade da escola católica no Brasil começou a mudar aceleradamente. A rapidez com que ocorreram as mudanças internas e externas, especialmente as de conjuntura política e econômica do Brasil nas ultimas duas décadas, deixaram a Escola Católica sem um norte. 
O boom do ensino público, o crescimento do setor privado na educação dominado por um empresariado extremamente competente e organizado na área da gestão educacional, a ausência de recursos para a sua adequada manutenção, a falta de uma política clara por parte da Igreja para a sua presença no mundo da Educação, a pouca valorização, quando não um a declarada oposição, por parte do Episcopado nacional, criaram situações embaraçosas, conflituosas e bastante difíceis para a Escola Católica. Por essas razões todas, aliadas a uma acentuada crise vocacional, muitas Escolas Católicas encerraram suas atividades.

Mais recentemente, em consonância com toda a Igreja, os leigos são cada vez mais numerosos nas suas escolas, inclusive nos quadros dirigentes das suas instituições educacionais. Os conflitos se intensificaram, ora com alunos e famílias devido às mensalidades escolares, ora com os sindicatos das categorias profissionais, ora com os mais variados órgãos públicos. Tudo isso concorre para situações que dificultam a sobrevivência da Escola Católica que deseja ser fiel à sua Missão e perseverar nos padrões éticos que sempre a conduziram.

Nos últimos anos, segmentos do Governo Federal vem sistematicamente deferindo os mais variados golpes contra as escolas católicas e as suas entidades mantenedoras. Um verdadeiro cipoal de legislações acirra uma conjuntura que peca contra o estado democrático que se deseja ver definitivamente instalado no Brasil, quando se desrespeita flagrantemente o direito à liberdade de ensino.

Os golpes de natureza política constantemente deferidos contra a Escola Católica ameaçavam a sua sobrevivência e a manutenção de seus direitos constitucionais referentes à imunidade e isenções, aliadas às crescentes demandas nas áreas jurídica, contábil, administrativa e outras, levaram a fundação, em agosto de 1993, da Associação Nacional de Mantenedoras de Escolas Católicas do Brasil - ANAMEC. Hoje, a legal e legítima representante desta secular instituição.

Muito mais haveria para ser apresentado e analisado sobre a Escola Católica no Brasil nestas três últimas décadas, o que sem dúvida exigiria um outro trabalho, de escopo distinto do presente. Para tal existe farto material à disposição dos interessados.

\section{Algumas convicções e certezas, à guisa de conclusão}

A presença da Igreja no campo da Educação tomou os contornos que os distintos momentos conjunturais de nossa história lhe imprimiram. Os momentos de dificuldades superados, os modelos de seu perfil jurídico adaptados às transformações de regime, das formas de governo e das constituições, 
e as crises internas alavancando novo ardor apostólico, vinham apenas confirmar a certeza de que, na sua Missão, Evangelização e Educação são indissociáveis. A Escola Católica é, pois, parte integrante de sua Ação Pastoral.

Diante das evidências dessa história, feita de entranhado serviço à juventude brasileira na constituição social, cultural e religiosa de nosso povo, fica fácil atestar a relevância da ação da Escola Católica ontem e hoje.

Enormes são para o Brasil os benefícios em poder continuar contando com a participação desta instituição, a Escola Católica, no seu desenvolvimento social e econômico, na formação das novas gerações às dimensões ética e de cidadania, e na consolidação de uma real democracia.

A sua tradição sem igual, a seriedade de seus princípios e a qualidade de seus serviços educacionais, a habilitam sobejamente a estar presente, hoje e amanhã, no Sistema Nacional de Educação de nossa Pátria, certa de poder continuar a oferecer a sua decisiva parcela de contribuição na construção da Nação.

A par destes desafios e certezas, e às vésperas de celebrar o Quinto Centenário de sua ação evangelizadora e educacional em nosso país, a Igreja Católica reafirma a convicção na eficácia de sua presença junto à juventude e o compromisso de sua presença no mundo da Educação, para construir uma sociedade pluralista, justa e solidária.

\section{Notas}

1 Modelo predominante desde Constantino (Edito de 313) até o Concílio Vaticano II (1962). A Contra-Reforma (Concílio de Trento), como reação à Reforma Protestante, determinou uma série de profundas mudanças na Igreja daquela época. O referido modelo de Cristandade era marcado por uma Igreja que se confundia com o estado, se impondo como fator determinante de todos os mecanismos e instâncias sociais.

2 O processo pelo qual, de um modo muito particular no caso de Portugal, o Estado controla uma certa Igreja local. Eram as Bulas Papais (sobretudo de 1455 a 1515) que estabeleciam, como direito da Coroa portuguesa, os "Padroados", nome como tal processo ficou conhecido. A instituição do "Padroado", anterior à descoberta, fazia da Coroa portuguesa o patrono das Missões católicas e das instituições eclesiásticas na África, Ásia e, posteriormente, no Brasil. Foi o "Padroado que incentivou e sustentou missionários em terras coloniais, antecipando-se à Igreja de Roma. Somente a partir do século XVII é que Roma passaria a preocupar-se com a evangelização do mundo colonial, procurando, então, restringir a ação do "Padroado". Em 1622 cria a Congregação para a Propagação da Fé.

3 Por mais de meio século o Brasil sujeitou-se à jurisdição do bispado de Funchal. A primeira diocese brasileira, a de São Salvados da Bahia, foi criada em 1551, a segunda Sé Episcopal somente em 1676, e em 1750 havia o inexpressivo número de sete dioceses no Brasil.

4 Associações leigas, reunidas em torno de um Santo Padroeiro, eram dirigidas por uma hierarquia e com atividades particulares. Algumas chegavam a acumular riquezas, e também conquistar influências políticas através de seus membros que gozavam de prestígio social.

5 As Ordens Religiosas tinham, por força do Direito Canônico, do Direito Próprio e de seus Superiores, um contato direto com Roma, o que lhes acentuava a autonomia em relação a Coroa portuguesa e ao Governo Colonial no Brasil.

6 A primeira manifestação real neste sentido encontra-se na Carta de Doação de D. João III a Pero Lopes 
A escola católica, uma história de serviço ao povo e à nação brasileira

em 1535. Mais tarde, a fim de obter a unidade, o controle e a representação da Metrópole Portuguesa, foi instituído o Governo Geral pela legislação de 17 de dezembro de 1548, promulgada pelo Rei de Portugal, Dom João III.

7 A Sociedade de Jesus - SJ (jesuítas) foi fundada m 1534 pelo espanhol Inácio de Loyola, nobre e militar, no contexto da Contra-Reforma, e, por isto mesmo, muito ligada ao Papado, com o propósito de defesa da Fé. Os Jesuítas criaram sua Província Portuguesa em 1542 por convite de Dom João III. Eles se estabeleceram em Coimbra onde dirigiram um Colégio e a Universidade, formando durante muito tempo diversas gerações de missionários para as obras do Brasil, e também intelectuais, seja para a Metrópole, seja para a Colônia brasileira.

8 Os impostos eram recolhidos através da "Redízima" instituída em 1564 (10\% dos impostos das capitanias recolhidos para a Corte se destinavam aos jesuítas.

9 Neste momento ainda sob a direção dos Jesuítas.

10 O tratado de Methen, de 1703, estabelecia a permuta comercial entre os manufaturados ingleses e a produção agrícola portuguesa, especialmente 0 vinho.

11 Devido à morte do Rei D. Sebastião, na batalha dos Três reis no Marrocos, o trono de Portugal passou a ser disputado. O Rei da Espanha fez valer o seu direito de sucessão e o ocupa. Os Reis Felipe II, III e IV de Espanha, respectivamente I, II e III de Portugal governaram este país de 1580 a 1640.

12 Um acontecimento que caracteriza bem este momento ficou conhecido, em 1874, como "Questão Religiosa", do qual o principal protagonista foi Dom Vital Maria Gonçalves de Oliveira. Ele integrou um movimento nacional que o Papa Pio IX (1846-1878) havia começado. O Papa intencionava combater alguns sérios problemas enfrentados pela Igreja daquela época, entre os quais o da falta de autoridade romana sobre a Igreja de certos países, como era o caso do Brasil. O documento pontifício publicado em 1864 contra os erros do mundo moderno chamava-se Syllabus.

13 Este Colégio e Seminário fundado no interior de Minas Gerais ficará famoso na História do Brasil. Um bom número de presidentes da primeira República estiveram sentados em seus bancos.

14 Análise semelhante encontra-se em Baudelot, Christian e Stablet, Roger in Ecole Capitaliste en France. Paris, Édition Maspero, 1971.

15 Em 1905 o Brasil recebe o primeiro cardinalato da América Latina, na pessoa do Arcebispo do Rio de Janeiro, o Cardeal Dom Joaquim Arcoverde.

16 Segundo estatísticas do CERIS de 1946, dois terços do clero brasileiro era integrado por estrangeiros.

17 Isso não foi originalidade da Igreja no Brasil. Uma análise histórica mais profunda e detalhada da doutrina pastoral da Igreja pós Reforma Protestante permitiria perceber a clara intenção de exercer sua ação evangelizadora e social através e com a colaboração das elites. Estratégia encontrada em movimentos que ainda em nossos dias vêm recebendo grande impulso do atual Papado.

18 Encontra-se no contrato entre a Ordem Terceira do Carmo, proprietária de um famoso Colégio em São Paulo e uma Congregação Religiosa que assumiu a direção do mesmo, datado de 14 de janeiro de 1912, o seguinte teor: "1. Os alunos do curso secundário pagarão $10 \$ 00$ (dez mil réis) mensalmente; os alunos do primário, $5 \$ 00$ (cinco mil réis); 2 . Os Irmãos não matricularão nunca menos que 20 alunos pobres e quando o número de alunos matriculados superar 400, eles inscreverão mais $5 \%$. De 250 alunos em 1900, as matrículas foram a mais de 600 em 1920, o que significou mais de 30 alunos gratuitos nos anos seguintes. É claro que a preferência das matrículas era para os filhos dos veneráveis confrades da Ordem do Carmo, mesmo que não fossem tão necessitados como os outros". José, Sulpício. Biografia do Irmão Mário Cristovão. Belo Horizonte. Centro de Estudos Maristas, 1989. p. 19 e20.

19 Existe uma vasta literatura, pesquisas e documentação, acerca deste período da Educação Católica no Brasil. Sem dúvida este período foi bem analisado em obras de fácil acesso. 


\section{Referências}

AVANZINI, Guy et alii. Histoire de la pédagogie du 17ème siècle à nos jours. Toulouse: Privat, 1988.

AZEVEDO, Fernando. A Cultura Brasileira. São Paulo: Melhoramentos, 1958. tomo 3 .

BAUDELOT, Christian e Stablet. Roger in Ecole Capitaliste en France. Paris: Maspero, 1971.

BEAULIEU, G. et al. Educação Brasileira e Colégio de Padres. São Paulo: Herder, 1996.

BOURDIEU, Pierre. La Noblesse d'Etat; grandes écoles et esprit de corps. Paris: Minuit, 1989.

FAUSTINO, João et al. Ir. Afonso; fundador da PUCRS. Porto Alegre: EPECE, 1987.

HADDAD, Sérgio. A Escola Católica: seu passado, seu presente, seu futuro. In: ____. A Educação na América Latina: continente em vias de desenvolvimento. São Paulo: Ammed, 1981,

RIBEIRO, Maria Luiza Santos. História da Educação Brasileira; a organização escolar. 9 ed. São Paulo: Cortez, 1989.

ROMANELL, Otaíza de Oliveira. História da Educação no Brasil. 11 ed. Petrópolis: Vozes, 1989.

SODRÉ, Nelson Werneck. História da Cultura Brasileira, Rio de Janeiro: Civilização Brasileira, 1970. 